\title{
Placental Polyp - A Rare Case Report
}

\section{Plasental Polip - Nadir Bir Olgu Sunumu}

\section{Vissa SHANTHI, Nandam Mohan RAO, Gundrajakuppam LAVANYA, Baddukonda Appala Rama KRISHNA, Kuppili Venkata Murali MOHAN}

Department of Pathology, Narayana Medical College, Nellore, ANDHRA PRADESH, INDIA

\begin{abstract}
Placental polyp is the retained fragment of placental tissue after the parturition or abortion for indefinite period which forms a polypoidal mass in the uterus. It is predominantly composed of necrotic and hyalinized chorionic villi (ghost chorionic villi). We report a case of 26-year-old G2P2 woman presenting with vaginal bleeding. Her last pregnancy had occurred five years ago. Laboratory investigations revealed a positive urine pregnancy test and serum levels of beta-human chorionic gonadotrophin ( $\beta$-hCG) was elevated. Ultrasonography revealed hyperechoic mass in uterine cavity. She underwent total abdominal hysterectomy and the pathological diagnosis was of a placental polyp.
\end{abstract}

Key Words: Polyps, Retained placenta, Pregnancy

\begin{abstract}
ÖZ
Plasental polip; doğum ve düşük sonrası belirsiz bir sürede ortaya çıkan, uterusta polipoid bir kitle yapan, atılmamış plasental doku fragmanıdır. Başlıca nekrotik ve hyalinize koryonik villuslardan (hayalet koryonik villus) oluşur. Burada vajinal kanama şikayeti ile gelen 26 yaşında G2P2 bir kadın olgusu sunulmaktadır. Son doğum öyküsü 5 yll öncesine aittir. Laboratuvar incelemeleri pozitif idrar gebelik testi ve yüksek insan koryonik gonodotropin ( $\beta-\mathrm{hCG}$ ) düzeyini gösterdi. Ultrasonografi uterin kavitede hiperekoik bir kitleyi ortaya koydu. Hastaya total abdominal histerektomi yapıldı ve patolojik incelemede plasental polip tanısı kondu.
\end{abstract}

Anahtar Sözcükler: Polipler, Ayrılmamış plasenta, Gebelik

\section{INTRODUCTION}

A placental polyp is the retained placental tissue which presents as a polypoidal or pedunculated mass with in the uterus. The placental tissue is retained either after the parturition or incomplete abortion. Hysterectomy is inevitable in life-threatening situations. For the women in the reproductive age group or women who want to preserve the fertility, the placental polyp can be managed by evaluating the neovascularization by multimodal imaging. Our case has been reported due to its rarity.

\section{CASE REPORT}

A 26-year-old G2P2 woman referred to the gynecologic department with a history of irregular vaginal bleeding and abdominal pain for one week. On her medical history, she had a normal vaginal delivery five years ago and there were no postpartum complications. She had normal menstrual history and her last period was two weeks ago. A hemorrhagic mass protruding from the external os of the cervix measuring approximately $3 \mathrm{~cm}$ in diameter was seen on her pelvic examination. The parametrium, both adnexae and uterus were normal. Clinically it was suspected to be cho-

(Turk Patoloji Derg 2015, 31:77-79)

Received : 16.01.2012 Accepted : 27.03.2012 riocarcinoma. The urine pregnancy test were found to be positive and serum level of beta hCG was $206.92 \mathrm{mIU} / \mathrm{ml}$. A heterogenous, hyperechoic mass was seen in the uterine cavity on the abdominal ultrasound. Total abdominal hysterectomy was performed due to the uncontrolled bleeding occurred during the biopsy procedure.

On gross examination uterus showed a pedunculated hemorrhagic mass attached at the fundal region measuring $6 \times 4 \times 3.5 \mathrm{~cm}$ (Figure 1). Microscopically, the sections from the pedunculated mass revealed organized blood clot with few ghost villi showing fibrin deposition (Figure 2), intermingled with normal trophoblastic villi (Figure 3) and numerous small arterioles. Due to these features the diagnosis of placental polyp was made. The post operative course was uneventful and on the sixth day the $\beta$-hCG was negative $(1.2 \mathrm{mIU} / \mathrm{ml})$.

\section{DISCUSSION}

The placental polyp is a rare entity and its estimated incidence is around 1 in 40,000-60,000 deliveries (1). Baer reported a case of placental polyp that occurred 12 years after the pregnancy in 1884 and this entity has been recognized since

Correspondence: Vissa SHANTHI

Narayana Medical College, Department of Pathology, Nellore, ANDHRA PRADESH INDIA

E-mail: santhijp@gmail.com Phone: +91984905 2179 


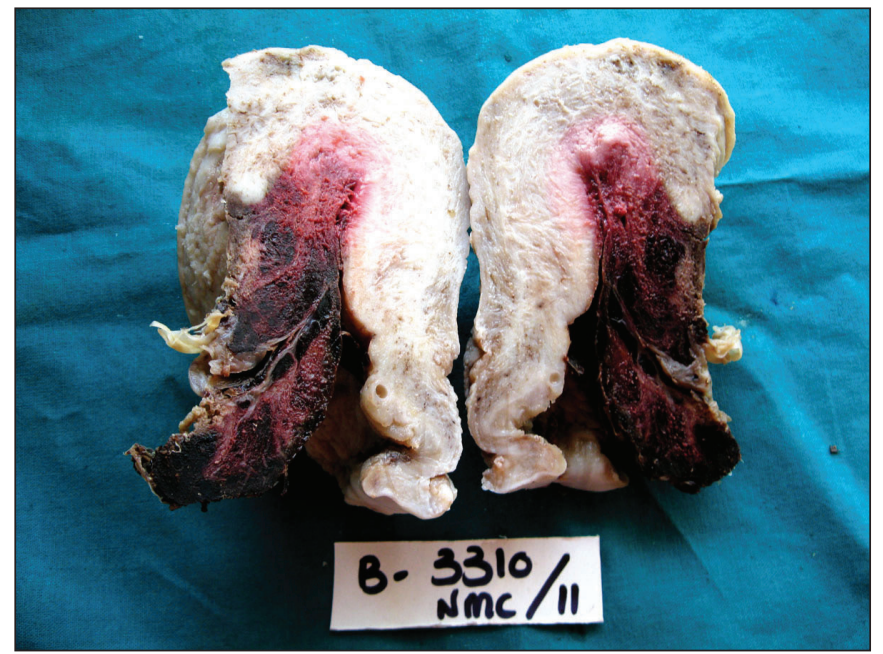

Figure 1: Pedunculated hemorrhagic and necrotic mass attached at the fundal region of uterus.

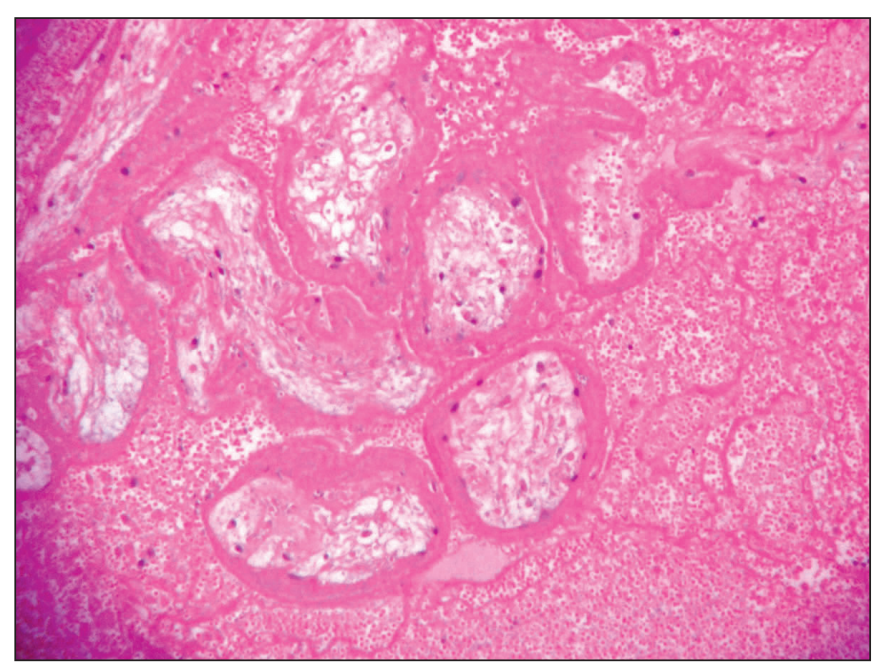

Figure 2: Hyalinized chorionic villi (Ghost villi) (H\&E; x100).

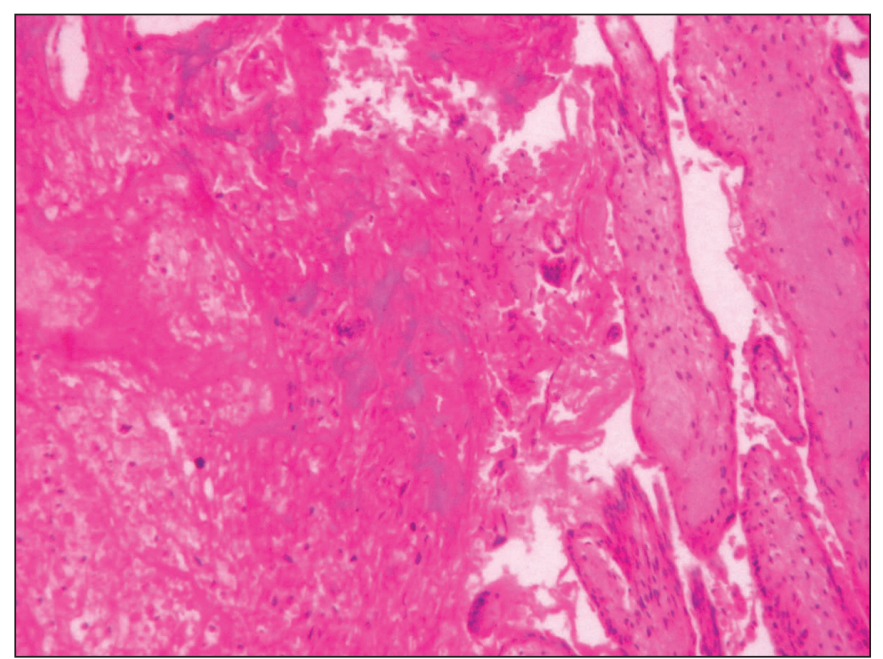

Figure 3: Normal chorionic villi admixed with ghost villi (H\&E; $\mathrm{x} 100)$. then (2). Remnants of placenta or membrane attached to the uterine wall and fibrin deposition around the remnants are usually considered pathognomonic of the formation of placental polyps (3).

Placental polyps are of two types. The first type which occurs in the first four weeks after postparturition period is termed as acute and the other one which occurs months or years later is termed as chronic type (4). Acute type of placental polyps is more common. A few cases were reported 5 years after attaining menopause, 20 years after delivery and even without documented pregnancy (5). Our case presented 5 years after her last pregnancy.

Pathogenesis of the placental polyps has been explained by two major theories. According to the first theory, the placenta is attached to the cornual or fundal myometria and is easily retained as the myometrium in this region is thin and atonic. Second theory suggests that the placenta accreta leads to the retention of placental tissue as the villi in this condition are directly attached to the underlying myometrium due to the defective decidua, especially in the cornual region. Hence the cornu or fundus becomes the most common sites for the placental polyps. In our case, placental polyp was attached at the fundus and the microscopic examination revealed trophoblastic villi invading the myometrium at the site of attachment of polyp. The factors responsible for the survival of these villi are still not clear however these surviving villi are responsible for the production of the human chorionic gonadotrophin (hCG) which was elevated in our case similar to the cases in the literature.

Most of the acute type of placental polyps present with postpartum hemorrhage and the chronic type presents with massive bleeding associated with pelvic pain. Few cases show a mass protruding out from the external os (6).

Other tumors of trophoblastic origin such as choriocarcinoma and placental site trophoblastic tumor also have similar gross appearance and elevated hCG level (7). Histologically, the placental polyp contains predominantly the ghost villi which are hyalinized and necrotic, and without lining trophoblast. Some of the chorionic villi show a rim of syncytiotrophoblasts that were viable. The base of the placental polyp contains abundant decidualized stroma with dilated and congested blood vessels. The features favouring the diagnosis of placental site trophoblastic tumor are nodules composed of intermediate trophoblastic cells arranged in cords, nests, irregular clusters or scattered within the eosinophilic hyalinized or fibrinoid matrix. The cells have irregular and lobated nuclei and amphophilic or 
clear cytoplasm. Villi are not seen in this condition. In our case, the diagnosis of choriocarcinoma was ruled out due to the presence of villi, absence of nuclear pleomorphism and low levels of hCG.

Though there is availability of various imaging modalities like USG with color Doppler signal, power Doppler imaging and magnetic resonance imaging (MRI), the preoperative diagnosis of placental polyp is rarely made. USG imaging of the placental polyp shows a heterogenous polypoid mass with prominent vascular flow (8). MRI and power Doppler imaging can more accurately detect abundant blood supply of the placental polyps rather than conventional color Doppler signal USG (9). These imaging techniques help in planning further management of this condition.

Most cases are treated by hysterectomy due to uncontrolled bleeding which is unresponsive to medication or further exacerbation by dilation and curettage. In some cases where the preservation of fertility is required, the placental polyps can be managed by conservative vaginal resection or hysteroscopic removal after the selective transarterial embolization (10) or even by administration of the methotrexate instead of surgery (11).

In conclusion; placental polyp is a rare entity which has similar clinical features as the other diseases. Histopathological examination of tissue is required to ascertain diagnosis. Although sonography shows a placental polyp, it is not helpful in differentiating the polyps from other masses in the uterus such as hydatidiform moles or degenerated submucosal uterine leiomyomas. To preserve fertility and lessen morbidity in the cases of placental polyp, an optimal investigation and management with efficient planning is required.

\section{REFERENCES}

1. Watcharotone W, Chairat Leelaphatanadit C. Placental polyp: A case report. Siriraj Med J. 2005;57:391-2.

2. Baer BF. Placental polypus which simulated malignant disease of the uterus. Philadelphia Med Times. 1884;15:175.

3. Yi JG, Choi SE, Shin YK, Lee JH. Placental polyp: Sonographic findings. Am J Radiol. 1993;161:345-6.

4. Dyer I, Bradburn DM. An inquiry into the etiology of placental polyps. Am J Obstet Gynecol. 1971;109:858-67.

5. Swan RW, Woodruff JD. Retained products of conception, histologic viability of placental polyps. Obstet Gynecol. 1969;34: 506-14.

6. Hatada Y. An unexpected case of placental polyp with villi devoid of cytotrophoblastic cells. J Obstet Gynaecol. 2004;24:193-4.

7. Soma H, Okada T, Yoshinari T, Furuno A, Yaguchi S, Tokoro K, Kato H. Placental site trophoblastic tumor of the uterine cervix occurring from undetermined antecedent pregnancy. J Obstet Gynaecol Res. 2004;30:113-6.

8. Takeda A, Koyama K, Imoto S, Mori M, Sakai K, Nakamura H. Placental polyp with prominent neovascularization. Fertility Sterility. 2010;93:1324-6.

9. Kanaoka Y, Maeda T, Nakai Y, Imanaka M, Ogita S. Placental polyp: Power Doppler imaging and conservative resection. Ultrasound Obstet Gynecol. 1998;11:225-6.

10. Takeuchi K, Ichimura H, Masuda Y, Yamada T, Nakago S, Maruo T. Selective transarterial embolization and hysteroscopic removal of a placental polyp with preservation of reproductive capacity. J Reprod Med. 2002;47:608-10.

11. Yamamasu S, Nakai Y, Nishio J, Hyun Y, Honda KI, Hirai K, Ishiko O, Ogita S. Conservative management of placental polyp with oral administration of methotrexate. Oncol Rep. 2001;8:1031-3. 